\title{
Different substrate compositions in the development of Brazilian berry in pots
}

\begin{abstract}
The Brazilian berry (Pliniacauliflora, sin: Myrciariacauliflora Berg), a native tree of the Brazilian Atlantic Forest, called by native people as "Jabuticaba" and cultivated throughout the national territory, is a species produced for consumption in natura, manufacturing liqueurs, ice cream, fermented drinks and juices, jellies, in addition to be used in the pharmaceutical industry for essential oil production. Despite being a tree species, it has been cultivated in pots by those who have little space. Thus, this study aimed to verify substrate compositions with soil in the development of Brazilian berry in full sun and potted. The experimental design was completely randomized, with 3 treatments and 9 replications, being: T1 - Soil + organic compost (1:1); T2 - Soil + sand (1:1); T3 - Soil + sand + organic compost (1:1:1). Chemical and physical properties of substrate mixtures, chlorophyll index and fresh and dry matter of leaves and analysis of leaf macro and micronutrients content were evaluated. Among the evaluated treatments, soil + sand + organic compost $(1: 1: 1)$ showed favourable results for the evaluated characteristics, while soil + sand (1:1) showed unfavourable results, probably due to the presence of sand in its mixture.
\end{abstract}

Keywords: plinia cauliflora, myrciaria cauliflora, myrtaceae, leaf nutrient, bioactive compound

\section{Introduction}

The Brazilian berry tree (Plinia cauliflora, sin: Myrciaria cauliflora Berg), called by native people as "Jabuticaba", belonging to the Myrtaceae family, is a native tree of the Brazilian Atlantic Forest and cultivated throughout the national territory. Medium-sized, it is a branched plant, approximately 10 to 15 meters tall, with a dense and elongated crown, with white flowers located along the trunk and with rounded fruit with dark skin, with seeds surrounded by a whitishcoloured pulp and sweet flavour. ${ }^{1}$

In the Myrtaceae family there are many species with medicinal properties; Pliniatrunciflora (O. Berg) Kausel is presented in the trunk bark properties used in the treatment of vision problems and asthma. ${ }^{2}$ The fruit has in its composition flavonoids, tannins, phenols, which help to prevent diseases, in addition to its great nutritional value. ${ }^{3}$ The peel also contains high content of anthocyanins and also pectin, vitamins $\mathrm{E}$ and $\mathrm{C},{ }^{4}$ in addition of flavonoids, with anticarcinogenic and antioxidant activities. ${ }^{5}$

The plants of this family are also recognized for the production of essential oils, ${ }^{6}$ and from leaves, there are reports of Eugeniadysenterica DC, with antifungal activity on Cryptococcusneoformans var. neoformans, human systemic fungus with high prevalence in immunocompromised patients: ${ }^{7}$ Myrciariatenella oil, with antimicrobial effect on Enterobacter sp and Shigellaflexneri; ${ }^{8}$ and Eugeniauniflora is popularly recommended against gout ${ }^{9}$ and has an antioxidant effect. ${ }^{10}$

The essential oil constituents of $P$. cauliflora leaves are: eudesmol, monoterpenes, $\alpha$-eudesmol, germacrene, $\beta$-eudesmol, (E)-caryophyllene, and bicyclogermacrene, among others, and there is a similarity between volatile compounds from leaves and fruits, which "dictates the possibility of using the leaves to obtain a natural Brazilian berry aroma, which could be used in perfumes, cosmetics and foods". This oil has aroused economic interest in the cosmetics industry, precisely because it is still an unknown aroma, and in the pharmaceutical industry, as many essential oils have antimicrobial activity. ${ }^{11,12}$ techniques. ${ }^{17}$
Volume 5 Issue 5 - 202 I

\author{
Jéssica Cristina Meira Bezerra,' Brian Turati \\ Rezende,' Jose Antonio Agustini,' Patrick \\ Luan Ferreira dos Santos, ${ }^{2}$ Maximiliano \\ Kawahata Pagliarini, ${ }^{3}$ Regina Maria Monteiro \\ de Castilho' \\ 'School of Engineering, São Paulo State University, Brazil \\ ${ }^{2}$ School of Agriculture, São Paulo State University, Brazil \\ ${ }^{3}$ Experimental Farm of Agrarian Science, Grand Dourados \\ Federal University, Brazil
}

Correspondence: Regina Maria Monteiro de Castilho, School of Engineering,São Paulo State University, Brasil Avenue, 56, Ilha Solteira, São Paulo state, Brazil,Tel +55 18 3743-1000, Email regina.castilho@unesp.br

Received: July 29, 2021 | Published: December 02, 2021 from fruit leaves is genetically determined, but may be influenced by abiotic factors, such as light, seasonality, temperature, levels of nutrition and water, soil, among others. ${ }^{6}$

On the other hand, the commercialization of the species is due to its great organoleptic function, being appreciated its consumption in natura, liqueurs, ice cream, fermented drinks, juice and jellies, as well as the fruits are used in pharmaceutical industry, as mentioned above, due to the high content of antioxidant substances. ${ }^{5}$ Despite being a tree with large fruit production in a single plant, after harvest the fruit has up to three days of shelf life, hindering its commercialization. ${ }^{13}$

In addition to its important chemical properties, the Brazilian berry tree has a great ornamental value, being appreciated in landscaping for its architectural exuberance, flowering and fruiting. ${ }^{5}$ The ornamentation of fruit growing adds value and diversifies production, facilitating its commercialization in the vegetative phase until seedlings producing fruit.

An important factor for ornamental cultivation is the container in which the plant will be cultivated, and the most used form is in pots. ${ }^{14}$ The main method of propagation of Brazilian berry tree is by seeds, but also by asexual propagation, however, the species is difficult to root; like other species of the same family (Eugeniauniflora L., Eugenia involucrata, Eugenia pungens) thus, the first type of propagation is widely chosen due to techniques used in the process of obtaining rootstocks, in the maintenance of variability and genetic improvement. ${ }^{15}$

One of the obstacles faced by producers and nurserymen is related to the lack of uniformity between the seedlings is the long juvenile period, whose variation may be from eight to twelve years to reach maturity. ${ }^{16}$ A protocol to be used for the efficient production of seedlings has not been defined yet, requiring the improvement of

In addition to the container, one of the most important and determining factors for the success of plant production outside the 
soil is precisely to find an environment that resembles it in physical and chemical conditions for the development of plant, in which case the substrate will be paramount for success of the production chain.

The ideal substrate must have good porosity, resistance to microorganisms and pathogens, offering a homogeneous composition, as well as being proportional to the development of the root system, as it will be the source of water, nutrients and oxygen for plants. ${ }^{18,19}$

An important point is the materials that are part of substrate composition might be easily available and found in sufficient quantity close to the production site, in addition to having an affordable price. In general, materials from agribusiness or agricultural processes meet these conditions, such as peanut or castor bean husks, sisal mucilage, ashes, sugarcane bagasse, oil extraction cake, etc. ${ }^{20}$ in addition to soil from the region may be used as a component, sand and organic compounds produced in local.

Substrates that have greater porosity and lower water retention capacity, such as sand, carbonized rice husks, need more frequent irrigations compared to those that have greater retention capacity (organic compounds, peat, coconut fibres). ${ }^{21}$ The substrate must be able to supply the oxygen demand for the root system, the nutrients required by the plants and phytosanitary control, in addition to avoiding problems related to salinity. ${ }^{22}$

Thus, the aim of the present study was to evaluate the development of Brazilian berry tree (Plinia trunciflora (O. Berg) Kausel) in three substrate compositions in pots.

\section{Material and methods}

The work was performed between November 2019 and November 2020, at São Paulo State University (UNESP) - Campus of Ilha Solteira, Brazil $\left(51^{\circ} 06^{\prime} 35^{\prime}\right.$ 'W, $20^{\circ} 38^{\prime} 44^{\prime}$ 'S, altitude approximately $347.361 \mathrm{~m})$, conducted in full sun. Seedlings of hybrid Brazilian berry trees with approximately 2 years and $60 \mathrm{~cm}$ in height, produced by seeds purchased from a seedling nursery in the municipality of Araçatuba, São Paulo state, Brazil, were used; these were transplanted to $20 \mathrm{~L}$ black polyethylene pots in 3 treatments: $\mathrm{T} 1$ - Soil + organic compost (1:1); T2 - Soil + sand (1:1); T3 - Soil + sand + organic compost $(1: 1: 1)$.

The soil, Dystrophic RED LATOSOL, ${ }^{23}$ was collected at a depth of $0.0-0.20 \mathrm{~m}$; the organic compost originated from 90 days of decomposition of tree leaves and grass clippings, being the products of the Farm of Teaching, Research and Extension of UNESP (municipality of Selvíria, Mato Grosso do Sul state); medium coarse and washed sand was purchased from the local market.

For chemical and physical substrate properties evaluation, it was used methodology by Embrapa ${ }^{24}$ to assess chemical analysis, density, macroporosity, microporosity, total porosity and water retention.

Regarding plant development, the leaf chlorophyll index (LCI) was evaluated every 30 days after transplanting (DAT), using a portable electronic chlorophyll meter (Chlorophyllometer) ClorofiLOG CFL1030 (FALKER). Mature and fully expanded leaves from the four quadrants of the crown were selected, measuring one leaf per quadrant and using the average of each plant, repeating this procedure in seven collections.

In the same way that the LCI was evaluated, leaves of all treatments and replicates were collected at 235 DAT. These were packed in Kraft paper bags with identification, and weighed on a digital scale to obtain the fresh mass. Then, they were placed in a forced circulation oven, at a temperature of $65^{\circ} \mathrm{C}$ for 24 hours, for drying and again weighed to obtain the dry mass. After drying, the leaves were crushed using a knife mill, for fragmentation and homogenization.

Then, they were stored in transparent plastic bags, properly identified, to analyse $\mathrm{N}, \mathrm{P}, \mathrm{S}, \mathrm{K}, \mathrm{Ca}, \mathrm{Mg}, \mathrm{Cu}, \mathrm{Fe}, \mathrm{Zn}$ and $\mathrm{Mn}$, according to the methodology of Malavolta, ${ }^{25}$ at the Laboratory of Soil and Plant Tissue Analysis of the Department of Plant Science, Food Technology and Socio-Economic (UNESP - Ilha Solteira).

The experimental design was completely randomized, with 3 treatments and 9 replicates, considering each plant as an experimental unit. The results were submitted to analysis of variance ANOVA ( $p$ $\leq 0.05)$ and Tukey's test $(\alpha=0.05)$, using the SISVAR program for statistical analysis. ${ }^{26}$

\section{Results}

Although pure soil is not part of the treatments, it was analysed physically and chemically as well as the mixtures to make a comparison between them possible.

In relation to chemical analysis, the substrate $\mathrm{T} 1$ [Soil + organic compound (1:1)] presented the highest values for Phosphorus, Potassium, Sulphur, Copper and Manganese (Table 1). In the other hand, substrate T2 [Soil + sand (1:1)] highlighted in more characteristics such as Organic Mater, Calcium, Magnesium, Sum of bases, Cationic Exchange Capability, Saturation of bases, Boron, Iron and Zinc (Table 1).

Table I Chemical analysis of substrate mixtures:TI - Soil + organic compound (I:I);T2 - Soil + sand (I:I); T3 - Soil + sand + organic compost (I:I:I) in Brazilian berry trees development. Pure soil (S) was analysed for comparison

\begin{tabular}{|c|c|c|c|c|c|c|c|c|c|c|}
\hline & P-resina & OM & $\mathbf{p H}$ & $\mathbf{K}$ & $\mathbf{C a}$ & $\mathbf{M g}$ & H+Al & Al & SB & S-SO4 \\
\hline & mg dm3 & g dm3 & $\mathrm{CaCl} 2$ & \multicolumn{6}{|c|}{------------------mmolc dm3---------------- } & mg dm3 \\
\hline TI & $24 I$ & 39 & 6.1 & 14.9 & 109 & 47 & 15 & 0 & 170.9 & 23 \\
\hline T2 & 160 & 43 & 6.5 & 8.6 & 148 & 52 & II & 0 & 208.6 & 22 \\
\hline T3 & 148 & 38 & 6.4 & 8.1 & 81 & 35 & 12 & 0 & 124.1 & 23 \\
\hline \multirow[t]{3}{*}{$S$} & 7 & 20 & 5.1 & 13 & 13 & II & 20 & 0 & 25 & 3 \\
\hline & CEC & $\mathbf{v}$ & $\mathrm{Ca} / \mathrm{CTC}$ & Mg/CTC & $\mathbf{m}$ & B & $\mathrm{Cu}$ & $\mathbf{F e}$ & $M n$ & Zn \\
\hline & mmolc dm3 & \multicolumn{4}{|c|}{ 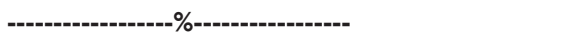 } & \multicolumn{4}{|c|}{ 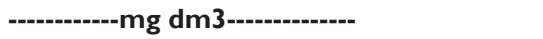 } & \\
\hline TI & 185.9 & 92 & 59 & 25 & 0 & 0.57 & 1.8 & 71 & 9.4 & 5.7 \\
\hline T2 & 219.6 & 95 & 67 & 24 & 0 & 0.67 & 1.4 & 66 & 7.1 & 5.9 \\
\hline T3 & 136.1 & 91 & 60 & 26 & 0 & 0.36 & 0.4 & 65 & 8.7 & 5.3 \\
\hline S & 45 & 56 & 29 & 24 & 0 & 0.07 & 0.9 & 23 & 6.4 & 0.3 \\
\hline
\end{tabular}

Citation: Bezerra JCM, Rezende BT,Agustini JA, et al. Different substrate compositions in the development of Brazilian berry in pots. Hort Int J Med. 202।;5(5): I8I-185. DOI: I0.15406/hij.202I.05.00227 
Regarding physical analysis, it is possible to notice that the most dense substrate was T2 with $1.52 \mathrm{~kg} \mathrm{dm}^{-3}$, followed by T3 $\left(1.31 \mathrm{~kg} \mathrm{dm}^{-3}\right.$ ) and $\mathrm{T} 1\left(1.10 \mathrm{~kg} \mathrm{dm}^{-3}\right)$. Analysing the porosity and its subdivisions, it was found that $24 \%$ was macropores in T2, being the substrate with more space among particles, followed by T3 (18.4\%) and T1 (15.2\%). In relation to micropores and total porosity, $\mathrm{T} 1$ presented the highest values for both, $41.9 \%$ and $57.1 \%$, respectively, while the smallest values were found at T2 (20.9\% and $44.8 \%$, respectively).

For water saturation, as soon as the water sample was removed (time 0 hour), the substrate $\mathrm{T} 1$ showed the highest retention $(0.607$ $\left.\mathrm{cm}^{3} \mathrm{~cm}^{-3}\right)$ and T2 the smallest $\left(0.413 \mathrm{~cm}^{3} \mathrm{~cm}^{-3}\right)($ Table 3$)$. Over the time, this relationship still continued, both after 24, 48 and 72 hours.

Table 2 Physical analysis of substrate mixtures:TI - Soil + organic compound (I:I);T2 - Soil + sand (I:I);T3 - Soil + sand + organic compost (I:I:I) in Brazilian berry trees development. Pure soil $(\mathrm{S})$ was analysed for comparison

\begin{tabular}{|c|c|c|c|c|}
\hline & Substrate density & Macroporosity & Microporosity & Total Porosity \\
\hline & $(\mathrm{kg} \mathrm{dm-3)}$ & \multicolumn{3}{|c|}{ 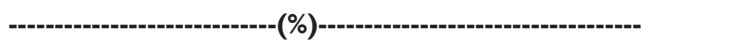 } \\
\hline TI & I.I & 15.2 & 41.9 & 57.1 \\
\hline T2 & 1.52 & 24 & 20.9 & 44.8 \\
\hline T3 & 1.31 & 18.4 & 32.4 & 50.8 \\
\hline$S$ & 1.27 & 14 & 39.2 & 53.2 \\
\hline
\end{tabular}

Table 3 Water retention of substrate mixtures:TI - Soil + organic compound (I:I);T2 - Soil + sand (I:I);T3 - Soil + sand + organic compost (I:I:I) in Brazilian berry trees development. Pure soil $(\mathrm{S})$ was analysed for comparison

\begin{tabular}{|c|c|c|c|c|}
\hline & \multicolumn{4}{|c|}{ Retained water $\left(\mathrm{cm}^{3} \mathrm{~cm}^{-3}\right)-$ Hours of drainage after substrate saturation } \\
\hline & 0 & 24 & 48 & 72 \\
\hline TI & 0.607 & 0.533 & 0.523 & 0.511 \\
\hline $\mathrm{T} 2$ & 0.413 & 0.431 & 0.413 & 0.389 \\
\hline T3 & $0.46 I$ & 0.492 & $0.46 I$ & 0.44 \\
\hline S & 0.487 & 0.506 & 0.487 & 0.464 \\
\hline
\end{tabular}

For plant development evaluations, the substrate that obtained the greatest leaves fresh mass accumulation was T1 (64.577 g), which after drying also showed the greatest dry mass accumulation $(37.944$ g). On the other hand, T2 was the substrate that presented the lowest averages of both: fresh mass $(43.155 \mathrm{~g})$ and dry mass $(27.255 \mathrm{~g})$ (Table 4).

Table 4 Fresh and dry mass $(\mathrm{g})$ of Brazilian berry leaves cultivated in three different substrate mixtures:TI - Soil + organic compound (I: I); T2 - Soil + sand (I:I);T3 - Soil + sand + organic compost (I:I:I)

\begin{tabular}{lll}
\hline & \multicolumn{1}{c}{ Fresh mass } & \multicolumn{1}{c}{ Dry mass } \\
\cline { 2 - 3 } & $-1 .-1$ & \\
\hline T1 & 64.577 & 37.944 \\
T2 & 43.155 & 27.255 \\
T3 & 60.033 & 36.388 \\
\hline
\end{tabular}

The leaf chlorophyll index (LCI) showed means with statistical difference when evaluating each substrate within each evaluation only for T2, but the difference was between the fourth (44.07) and sixth (35.67) evaluation.

Analysing each evaluation separately, it was observed that the statistical difference occurred only after the fifth evaluation (150 days after transplantation - DAT). In this evaluation, T1 (46.13) and T3 (45.76) did not differ statistically from each other, but both were different from T2 (40.01). The same occurred in the sixth evaluation, however, in the seventh evaluation T1 (46.30) was not different from T3 (44.64) and T2 (39.23) was not different from T3. The only statistical difference in the last assessment was between T1 and T2.
Means followed by the same uppercase letter in the row and lowercase letter in the column do not differ at the level of $5 \%$ by Tukey test.

The contents of macro and micronutrients are shown in Table 6 and it is possible to observe that there was a statistical difference only for nitrogen, magnesium and manganese.

For nitrogen and manganese, all substrates showed statistically different means, and $\mathrm{T} 1$ accumulated more $\mathrm{N}\left(15.75 \mathrm{~g} \mathrm{~kg}^{-1}\right)$ and $\mathrm{Mg}$ (4.98 $\mathrm{g} \mathrm{kg}^{-1}$ ) compared to the other treatments, followed by T3 $(\mathrm{N}-$ $14.27 \mathrm{~g} \mathrm{~kg}^{-1}$ and $\left.\mathrm{Mg}-4.76 \mathrm{~g} \mathrm{~kg}^{-1}\right)$ and finally $\mathrm{T} 2\left(\mathrm{~N}-12.37 \mathrm{~g} \mathrm{~kg}^{-1}\right.$ and $\left.\mathrm{Mg}-4.56 \mathrm{~g} \mathrm{~kg}^{-1}\right)$. 
In relation to manganese, the biggest difference presented in the accumulation of this mineral was between $\mathrm{T} 2$ and $\mathrm{T} 1$, being that the first presented $333.55 \mathrm{~g} \mathrm{~kg}^{-1}$ and the second $110.11 \mathrm{~g} \mathrm{~kg}^{-1}$, differing statistically between them.
Means followed by the same letter do not differ at the level of $5 \%$ by Tukey test.

Table 5 Leaf chlorophyll index (LCI) of Brazilian berry leaves, assessed each 30 days, cultivated in three different substrate mixtures: TI - Soil + organic compound (I:I);T2 - Soil + sand (I:I);T3 - Soil + sand + organic compost (I:I:I) over time

\begin{tabular}{|c|c|c|c|c|c|c|c|}
\hline & \multicolumn{7}{|c|}{ Evaluations } \\
\hline & $1^{\circ}$ & $2^{\circ}$ & $3^{\circ}$ & $4^{\circ}$ & $5^{\circ}$ & $6^{\circ}$ & $7^{\circ}$ \\
\hline & \multicolumn{7}{|c|}{ 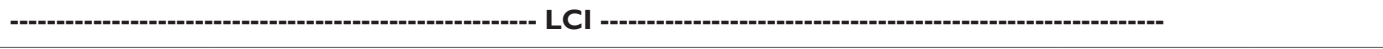 } \\
\hline TI & $40.45 \mathrm{Aa}$ & $45.62 \mathrm{Aa}$ & $44.62 \mathrm{Aa}$ & $47.08 \mathrm{Aa}$ & $46.13 \mathrm{Aa}$ & $47.34 \mathrm{Aa}$ & $46.30 \mathrm{Aa}$ \\
\hline T2 & $40.93 \mathrm{ABa}$ & $40.62 \mathrm{ABa}$ & $42.46 \mathrm{ABa}$ & $44.07 \mathrm{Aa}$ & $40.01 \mathrm{ABb}$ & $35.67 \mathrm{Bb}$ & $39.23 \mathrm{ABb}$ \\
\hline T3 & $40.15 \mathrm{Aa}$ & $46.05 \mathrm{Aa}$ & $44.86 \mathrm{Aa}$ & $45.84 \mathrm{Aa}$ & $45.76 \mathrm{Aa}$ & 43. II Aa & $44.64 \mathrm{Aab}$ \\
\hline
\end{tabular}

Table 6 Leaf analysis of macro and micronutrients in Brazilian berry trees cultivated in three different substrate mixtures:TI - Soil + organic compound (I:I); T2 - Soil + sand (I:I);T3 - Soil + sand + organic compost (I:I:I) at the end of experiment

\begin{tabular}{|c|c|c|c|c|c|c|}
\hline & $\mathbf{N}$ & $\mathbf{P}$ & $\mathbf{K}$ & $\mathrm{Ca}$ & Mg & $\mathbf{S}$ \\
\hline & -------- & |------------' & ---g kg-I & --.-- & ------------- & \\
\hline TI & $15.75 a$ & $1.64 \mathrm{a}$ & $7.92 \mathrm{a}$ & $12.14 \mathrm{a}$ & $4.98 a$ & $2.09 a$ \\
\hline $\mathrm{T} 2$ & $12.37 \mathrm{c}$ & $2.0 \mathrm{la}$ & $8.55 a$ & $12.77 \mathrm{a}$ & $4.56 c$ & $1.97 \mathrm{a}$ \\
\hline T3 & $14.27 \mathrm{~b}$ & $1.97 \mathrm{a}$ & $7.95 a$ & II.I Ia & $4.76 \mathrm{~b}$ & $2.63 a$ \\
\hline DMS & I.429** & $0.5 \mathrm{IIns}$ & $0.879 n s$ & $2.298 \mathrm{~ns}$ & $0.154 * *$ & I. I04ns \\
\hline \multirow[t]{2}{*}{$\mathrm{CV}(\%)$} & 8.31 & 22.41 & 8.87 & 15.73 & 2.66 & 40.64 \\
\hline & $\mathrm{Cu}$ & $\mathbf{F e}$ & & Mn & & Zn \\
\hline TI & $10.22 \mathrm{a}$ & $231.33 a$ & & $\mathrm{II} 0 . \mathrm{IIb}$ & & $24.44 a$ \\
\hline T2 & II.IIa & $218.11 \mathrm{a}$ & & $333.55 a$ & & $24.1 \mathrm{Ia}$ \\
\hline T3 & $10.00 \mathrm{a}$ & $225.33 a$ & & 163.77ab & & $23.22 \mathrm{a}$ \\
\hline DMS & $5.882 \mathrm{~ns}$ & $37.183 \mathrm{~ns}$ & & I77.69* & & $3.882 \mathrm{~ns}$ \\
\hline CV(\%) & 46.28 & 13.58 & & 72.11 & & 13.33 \\
\hline
\end{tabular}

\section{Discussion}

In the chemical analysis (Table 1 ) of substrate mixtures, it may be observed that all treatments presented higher values compared to pure soil, except potential acidity. Even though the pure soil was not part of the experiment, its analysis was taken as a control to show that a single element does not always have all the necessary characteristics to be a good substrate.

For Malavolta, ${ }^{27}$ in most crops, $\mathrm{pH}$ values close to or above neutrality are harmful to growth, where the ideal $\mathrm{pH}$ would be 5.5 to 6.5 , with a balance between the availability of nutrients and minimizing the action of toxic aluminium, which corroborates the work described by Hossel ${ }^{16}$ in which he found that Brazilian berry tree crop showed better growth with soil $\mathrm{pH}(\mathrm{CaCl})$ around 5.6. However, the species is native to areas with a high content of organic matter, with an extremely acidic $\mathrm{pH}$, usually below 5.28,29 The $\mathrm{pH}$ of the mixtures used in the present work (Table 1) ranged from 6.1 to $6.5(\mathrm{CaCl} 2)$, and although T2 had a higher value (6.5) it had lower fresh and dry mass (Table 4) in relation to $\mathrm{T} 1$ and $\mathrm{T} 3$, with $\mathrm{pH}$ of the mixtures at 6.1 and 6.4, respectively. Thus, at $\mathrm{pH} 6.1$ there was greater fresh and dry mass (Table 4).
For Mattos, ${ }^{30}$ soils for this crop should preferably be clayey and with good moisture. Although no particle size analysis was performed on the samples, Red Latosol was used as a substrate component, which according to Reichert et al. ${ }^{31}$ have density that may vary from 1.25 to $1.40 \mathrm{~kg} \mathrm{dm}^{-3}$, depending on the amount of clay, that is, the substrate mixtures were adequate when considering the density for the root development of Brazilian berry tree (Table 2).

In addition, Klein ${ }^{32}$ states that the Red Latosol density of at least $1.08 \mathrm{~kg} \mathrm{dm}^{-3}$ occurs the maximum water availability, in this case, it may be observed that there was great water retention in all substrates, highlighting $\mathrm{T} 1$ that did not contain sand in its formulation (Table 2 ). The author also states that values higher than this may affect aeration and hinder root development, in this case T2 substrate, which presented the highest density, surpassing the recommended density by 1.4 times, was the treatment that presented the lowest means of fresh and dry masses (Table 4), which clearly affected Brazilian berry tree development.

In a work conducted with seedlings formation of the same species and different substrates, ${ }^{15}$ proved that the presence of mixtures with sand in the treatments were inferior to the results of treatments with 
other mixtures, corroborating the present work, in which mixtures such as $\mathrm{T} 1$ and $\mathrm{T} 3$, containing organic matter, allowed a greater availability of nutrients (Table 1), increment of total porosity (Table 2 ), which reflected in accumulation of fresh and dry mass (Table 4).

In a study performed by Kosera Neto, ${ }^{33}$ with Brazilian berry trees grown in an orchard under full sun, the LCI ranged from 43.0 to 44.9 ; in the treatments of the present work (Table 5), the first evaluation is below the expected range, which may imply the reason for the stress suffered by the plant due to its transplantation. On the other hand, $\mathrm{T} 1$ and $\mathrm{T} 3$ in the other evaluations ( $2^{\text {nd }}$ to $\left.7^{\text {th }}\right)$ have the LCI values above the expected, whereas for $\mathrm{T} 2$ only in the $4^{\text {th }}$ evaluation the value is within the expected range, and the other evaluations values lower than found.

Lima et al. (2018) states that there is a relationship between the LCI and the production of dry biomass, values found in the present work show the relationship mentioned above, where $\mathrm{T} 1$ presents the best LCI results (Table 5), relating to the highest values of fresh and mass dry (Table 4).

\section{Conclusions}

The cultivation of Brazilian berry trees (Plinia cauliflora) seedlings cultivated in pots, with a mixture of soil + organic compost $(1: 1)$ proved to be more suitable for analysed characteristics.

\section{Conflicts of interest}

The authors declare no conflicts of interest.

\section{References}

1. Embrapa Florestas. Valor nutricional da jabuticaba; 2015.

2. Cruz AVM, Kaplan MAC. Uso medicinal de espécies das famílias Myrtaceae e Melastomataceae no Brasil. Floresta e ambiente. 2012;11(1):47-52.

3. Fernandes LL. Alimento funcional: propriedades da jabuticaba (Myrciaria cauliflora). Revista FAROL. 2018;6(6):49-60.

4. Simões RS, Mattos LS. Plantas (Frutos) com Propriedades Medicinais mais utilizadas no dia a dia; 2018.

5. Sassao SAZ, Citadin I, Danner MA. Propagação de Jabuticabeira por enxertia e alporquia. Revista Brasileira de Fruticultura,. 2010;32(2):571576.

6. Simões CMO, Schenkel EP, Mello JCP, et al. Farmacognosia: da Planta ao Medicamento. Porto Alegre: UFRGS/EDUFSC; 2005.

7. Costa TR, Fernandes OF, Santos SC, et al. Antifungal activity of volatile constituents of Eugenia dysenterica leaf oil. Journal of Ethnopharmacology. 2000;72:111-117.

8. Schneider NFZ, Moura NF, Marins K, et al. Estudo dos compostos voláteis e atividade antimicrobiana da Myrciaria tenella (cambuí). Revista Brasileira de Farmacologia. 2008;89(2):131-133.

9. Schmeda-Hirschmann G, Theoduloz C, Franco L, et al. Preliminary pharmacological studies on Eugenia uniflora leaves: xanthine oxidase inhibitory activity. Journal of Ethnopharmacology. 1987;21:183-186.

10. Theodoloz C, Franco R, Ferro E, et al. Xanthine oxidase inhibitory activity of Paraguayan Myrtaceae. Journal of Ethnopharmacology. 1988;24:179-183.

11. Estanislau AA, Barros FAS, Peña AP, et al. Composição química e atividade antibacteriana dos óleos essenciais de cinco espécies de Eucalyptus cultivadas em Goiás. Revista Brasileira de Farmacognosia. 2001;11:95-100.
12. Duarte AR. Chemical variability of essential oils and phenol content in leaves and fruits of jabuticabeira (Myrciaria cauliflora). Doctorate thesis. Universidade Federal de Goiás; 2012.

13. Lima AJB, Corrêa AD, Alves APC, et al. Caracterização química do fruto jabuticaba (Myrciaria cauliflora Berg) e de suas frações. Archivos Latinoamericanos de Nutrición. 2008;58(4):416-421.

14. Silva JB. Cultivo em vaso de Oliveira (Olea europaea L.) ornamental. Master Thesis. Universidade Federal de Pelotas; 2017.

15. Danner MA, Citadin I, Fernandes Junior AA, et al. Formação de mudas de jabuticabeira (Plinia sp.) em diferentes substratos e tamanhos de recipientes. Revista Brasileira de Fruticultura. 2007;29(1):179-182.

16. Hossel C. Crescimento de jabuticabeiras açu produzidas em diferentes intensidades luminosas e cultivadas em distintas condições de acidez do solo. Doctorate thesis. Universidade Tecnológica Federal do Paraná; 2019.

17. Silva JAA, Teixeira GHA, Martins ABG, et al. Advances in the propagation of jabuticaba tree. Revista Brasileira de Fruticultura. 2019;41(3):24.

18. Melo Junior CJAH. Efeito do esterco bovino na composição de substrato para produção de mudas de três espécies florestais da Mata Atlântica. Graduation monograph. Universidade Federal Rural do Rio de Janeiro; 2013.

19. Mello RP. Consumo de água do lírio asiático em vaso com diferentes substratos. Master thesis. Universidade Federal de Santa Maria; 2006.

20. Severino LS, Lima RSL, Beltrão NEM. Composição química de onze materiais orgânicos utilizados em substratos para produção de mudas. Campina Grande: Embrapa. Comunicado Técnico; 2006.

21. Lopes JLW, Guerrini IA, Saad JCC. Qualidade de mudas de eucalipto produzidas sob diferentes lâminas de irrigação e dois tipos de substrato. Revista Árvore. 2007;31(5):835-843.

22. Costa PC. Produção do tomateiro em diferentes substratos. Doctorate thesis. Universidade Estadual Paulista; 2003.

23. Sistema brasileiro de classificação dos solos. Brasília: Embrapa; 2018.

24. Manual de métodos de análise do solo. Rio de Janeiro: Embrapa; 2017.

25. Malavolta, E, Vitti GC, Oliveira SA. Avaliação do estado nutricional das plantas: princípios e aplicações. Piracicaba: Associação Brasileira para Pesquisa da Potassa e do Fosfato; 1989.

26. Ferreira DF. Sisvar: a computer analysis system to fixed effects split plot type designs. Revista Brasileira de Biometria. 2019;37(4):529-535.

27. Malavolta E. Manual de nutrição mineral de planta. São Paulo: CERES; 2006.

28. Cassol DA, Wagner Junior A, Pirola K, et al. Embalagem, época e ácido indolbutírico na propagação de jabuticabeira por alporquia. Revista Brasileira de Fruticultura. 2015;37(1):267-272.

29. Soares NB, Pommer CV, Sarmento BMM, et al. Jabuticaba: Instruções de cultivo. Porto Alegre: Cinco Continentes; 2001.

30. Mattos JR. As espécies da secção Cauliflorae Berg do gênero Myrtaciaria Berg (Myrtaceae). Comunicações avulsas de Botânica. 1970;51:33-35.

31. Reichert JM, Suzuki LEAS, Reinert DJ, et al. Reference bulk density and critical degree of-compactness for no-till crop production in subtropical highly weathered soils. Soil Till Research. 2007;102(2):242-254.

32. Klein VA. Densidade relativa - um indicador da qualidade física de um latossolo vermelho. Revista de Ciências Agroveterinárias. 2006;5(1):2632.

33. Kosera Neto C, Porto AH, Silva M, et al. Reproductive and vegetative behavior of hybrid jabuticaba tree under flowering induction. Pesquisa Agropecuária Tropical. 2018; 48(2);118-125. 